\title{
Organic amendments: effects on cereals growth and cadmium remediation
}

\author{
I. Ahmad • M. J. Akhtar • Z. A. Zahir • \\ B. Mitter
}

Received: 13 March 2014/Revised: 27 August 2014/ Accepted: 20 October 2014/Published online: 29 October 2014

(C) Islamic Azad University (IAU) 2014

\begin{abstract}
Cadmium (Cd) is one of the toxic metals that adversely affect plant growth. Organic amendments may not only enhance nutrient status of soil, but they may also form complexes with $\mathrm{Cd}$ and reduce its availability to plants. This experiment was conducted to determine whether organic amendments (compost and biogas slurry) could stabilize/extract $\mathrm{Cd}$ and alleviate the adverse effects of $\mathrm{Cd}$ on the growth of two cereals, wheat and maize. Organic amendments along with four varying levels of $\mathrm{Cd}$ $\left(0,5,20,50 \mathrm{mg} \mathrm{kg}^{-1}\right.$ soil) were prepared with soil. Effect of these amendments on tolerance indices, root/shoot dry biomass, tissue $\mathrm{Cd}$ concentration, Cd uptake and translocation were studied. Biogas slurry caused maximum increase in tolerance indices of wheat and maize (100-112 and $117-133 \%$, respectively, as compared to control), whereas compost caused significant increase in their dry biomass. Negative correlation between root dry biomass of wheat $(r=-0.37)$ and maize $(r=-0.53)$ to Cd revealed its suppressive effects. Dry biomass of plant correlated with organic amendments in wheat $(r=0.83-0.98)$, whereas weak correlation was observed in maize $(r=0.30-0.40)$. Compost significantly reduced Cd uptake in wheat and maize; however, it increased Cd translocation in plants. Based on the results of this study, root was the major sink of $\mathrm{Cd}$ when soil was amended with or without organic amendments. Biogas slurry removed $97 \% \mathrm{Cd}$
\end{abstract}

\footnotetext{
I. Ahmad $(\bowtie) \cdot$ M. J. Akhtar · Z. A. Zahir

Soil Microbiology and Biochemistry Laboratory, Institute of Soil and Environmental Sciences, University of Agriculture,

Faisalabad 38040, Pakistan

e-mail: iffises@yahoo.com

I. Ahmad · B. Mitter

Bioresources Unit, AIT Austrian Institute of Technology GmbH,

3430Tulln, Vienna, Austria
}

from artificially polluted water after $13 \mathrm{~h}$ at $\mathrm{pH}$ 6. The additions of compost in soil and biogas slurry in wastewater are recommended to stabilize/extract $\mathrm{Cd}$.

Keywords Bioremediation - Cadmium stress ·

Biosorption · Compost · Biogas slurry · Wheat · Maize

\section{Introduction}

The steadily growing population is increasing the production of municipal waste, which contains both organic and inorganic pollutants including heavy metals. The heavy metals are accumulated in soil through pedogenic and anthropogenic activities (Taghinia et al. 2010; Conceição et al. 2013; Moaref et al. 2014). The problem of heavy metals is associated with the proliferation of industry. Most of the waste generated by industries ultimately ends its journey in soil and water. Some of such industries causing metals build up in soil include textile, paint, electroplating, paper, mining and tannery industry (Azzaoui et al. 2002; Vutukuru 2003; Taghinia et al. 2010). Industrial effluents discharged from these industries are irrigating chunk of agricultural soils that causes problem of metal pollution. The untreated industrial effluents are the main source of metal pollution of peri-urban soils in developing countries (Mahmood 2010). It has also been reported that $\mathrm{Cd}$ is an inveterate toxicant and is easily passed through plants. Cadmium shows many deleterious effects in humans when they consume it through food (Vassilev et al. 1998). Therefore, it is a dire need to develop effective technology to curtail $\mathrm{Cd}$ contamination from soil.

Organic manures (compost, biogas slurry) are known to improve soil structure and soil fertility status by adding essential nutrients, and enhance microbial community of 
soil (Oldare et al. 2008, 2011). Application of organic manures is a common practice worldwide to enhance nutrient status of soil, and as a result, more production of crops is obtained (Muhammad et al. 2007). Compost produced from crop leftovers has been used as a nutrient source and also as a soil conditioner since the ancient times to improve growth and yield of crops (Hussain et al. 2001; Sarwar et al. 2007). Biogas slurry (BGS) being used as organic manure is produced from dung waste after methane $\left(\mathrm{NH}_{4}\right)$ generation. It has also been evaluated as a good nutrient source in various countries including Pakistan. Very recently, Shahbaz et al. (2014) reported increased fruit set and nitrogen use efficiency of okra with the addition of BGS to soil medium.

Most of the work done by several research groups focuses on organic manures (compost and BGS) as a way to improve soil fertility, but they may also be exploited for metal remediation from polluted soil and water. Addition of these organic amendments to soil is a way of enhancing natural mechanisms such as precipitation, complexation, adsorption and absorption, which reduces the bioavailability of the pollutants (Pérez-de-Mora et al. 2007). Moreover, these organic amendments provide a facility to establish plants on polluted soil by binding pollutants, increasing nutrients and stimulating native microbial community (Oldare et al. 2011; Zaniewicz-Bajkowska et al. 2007; Pérez-de-Mora et al. 2006, 2007). The revegetation of metal-contaminated soil could be possible by the application of compost prepared from municipal solid waste (Farrell and Jones 2010; Walker et al. 2004). Furthermore, compost is converted into a final stable product of humus that can reduce metal availability in soil by the formation of stable complexes (Walker et al. 2003).

Biosorption is a cost-effective, environment-friendly technology, which can be exploited for numerous pollutants irrespective of their toxicity. Furthermore, it takes less time to remove pollutants from wastewater without producing any toxic secondary metabolites. Natural products are being used to adsorb metals and slack down their concentrations from wastewater. El-Said et al. (2010) used rice husk ash to sorb metals from metal-contaminated aqueous solution. Use of a biological source to sorb contaminant from wastewater is an emerging technology, and scientists are interested to apply such low-cost materials to bind metals from wastewater (Sari and Tuzen 2009; El-Said et al. 2010). Although some work has been conducted on organic manures, there is still a need to explore the role of compost and BGS to stabilize/extract $\mathrm{Cd}$ and to improve cereal growth by mitigating $\mathrm{Cd}$ stress. Therefore, the present study was conducted to answer the following questions: (1) Can compost and BGS improve cereal growth by alleviating $\mathrm{Cd}$ stress and which one is more effective? (2) Can these organic amendments stabilize or sorb Cd from soil or solution?

\section{Materials and methods}

\section{Collection and analysis of manures}

The compost produced from fruit peels was collected from the locally fabricated unit at Institute of Soil \& Environmental Sciences, University of Agriculture Faisalabad, Pakistan. Biogas slurry was collected from the biogas plant located at Rissalawala village in Faisalabad and then airdried and crushed in a crushing unit to the final grain size of $5 \mathrm{~mm}$. The pre-analysis of organic amendments was carried out to determine total metal concentration, total nitrogen, electrical conductivity (EC) and $\mathrm{pH}$ (Table 1). Total metal concentration in organic manures was determined through dry ashing (Isaac 1998). Briefly, $1 \mathrm{~g}$ of manure sample weighed in crucibles and converted into ash in a muffle furnace at $550{ }^{\circ} \mathrm{C}$ for $4 \mathrm{~h}$. The crucibles having ash were cooled in a desiccator for $1 \mathrm{~h}$. Then, the ash was dissolved in $10 \mathrm{~mL} \mathrm{HCl}$, transferred it to a $100-\mathrm{mL}$ volumetric flask, and made the final volume with distilled water. The material was stored in plastic bottles and used for the determination of $\mathrm{Cd}$, $\mathrm{Pb}, \mathrm{Cr}, \mathrm{Ni}, \mathrm{Zn}$, and $\mathrm{Fe}$ in manures using an atomic absorption spectrophotometer (PerkinElmer, 100 Analyst, Waltham,
Table 1 Characteristics of compost and biogas slurry used in the experiments

\begin{tabular}{llllll}
\hline & Units & Compost & Biogas slurry & \multicolumn{2}{l}{ Permissible limits* } \\
\cline { 4 - 5 } & & & & EU range & USA \\
\hline $\mathrm{pH}_{1: 2}$ & - & 7.65 & 7.1 & $5.5-7.0$ & $6-7$ \\
$\mathrm{EC}_{1: 2}$ & $\mathrm{dS} \mathrm{m}^{-1}$ & 3.15 & 2.98 & - & - \\
Organic matter & $\%$ & 56 & 45 & $>20$ & $>30$ \\
Total N & $\%$ & 2.12 & 1.65 & - & - \\
Total Cd & $\mathrm{mg} \mathrm{kg}^{-1}$ & $2.13 \pm 0.31^{\dagger}$ & $1.94 \pm 0.11$ & $0.7-10$ & 39 \\
Total $\mathrm{Pb}$ & $\mathrm{mg} \mathrm{kg}^{-1}$ & $\mathrm{ND}$ & $\mathrm{ND}$ & $70-1,000$ & 300 \\
Total $\mathrm{Ni}$ & $\mathrm{mg} \mathrm{kg}^{-1}$ & $10.48 \pm 4.47$ & $17.35 \pm 4.45$ & $20-200$ & 420 \\
Total $\mathrm{Cr}$ & $\mathrm{mg} \mathrm{kg}^{-1}$ & $\mathrm{ND}$ & $\mathrm{ND}$ & $70-200$ & 1,200 \\
Total $\mathrm{Zn}$ & $\mathrm{mg} \mathrm{kg}^{-1}$ & $46.57 \pm 2.64$ & $81.82 \pm 4.50$ & $210-4,000$ & 2,800 \\
\hline
\end{tabular}


USA). Total nitrogen contents were determined using the Kjeldahl apparatus (Jackson 1962). Organic manures (compost and BGS) to water ratio 1:2 was made to determine $\mathrm{pH}$ and EC with the help of pH meter (Jenway Model-671P) and EC meter (Kent EIL Model 7015). Organic matter contents of compost and BGS were determined according to loss on ignition method using equation (Eq. 1).

$$
\begin{aligned}
& \text { Organic matter }(\%) \\
& =\frac{\text { Dry weight at } 105^{\circ} \mathrm{C}-\text { Dry weight at } 450{ }^{\circ} \mathrm{C}}{\text { Dry weight at } 105^{\circ} \mathrm{C}} \times 100 \text {. }
\end{aligned}
$$

\section{Seed material}

The seed of wheat (cv. Inqlab-91) was obtained from the Wheat Section, Ayub Agricultural Research Institute (AARI) Faisalabad, Pakistan, whereas that of maize (Pioneer Hybrid-3068) was purchased from a local supplier of Pioneer Seed Company Sahiwal, Pakistan. Before sowing, seeds were surface sterilized with $5 \%$ sodium hypochlorite solution for 5 min following 3-4 washings with distilled water.

\section{Cadmium treatment}

Cadmium chloride $\left(\mathrm{CdCl}_{2} \cdot \mathrm{H}_{2} \mathrm{O}\right)$ salt of high purity (98\%) was purchased from Merck Chemicals, Germany, and used to prepare desired $\mathrm{Cd}$ concentrations $\left(5,20,50 \mathrm{mg} \mathrm{kg}^{-1}\right.$ soil) along with control in which distilled water was used without Cd contamination.

\section{Experimental conditions}

Jar experiments were conducted to evaluate the effect of organic amendments (compost and BGS) on dry biomass of cereals and $\mathrm{Cd}$ uptake. Organic amendments (compost at the rate of 10 and $15 \mathrm{Mg} \mathrm{ha}^{-1}$ for wheat and maize, respectively, while BGS at the rate of $15 \mathrm{Mg} \mathrm{ha}^{-1}$ for both cereals) weighed and thoroughly mixed in sand ( $400 \mathrm{~g}$ for wheat and $500 \mathrm{~g}$ for maize depending upon the size of jar). The desired Cd levels [2, 8, and $20 \mathrm{mg} / \mathrm{jar}$ for wheat; 2.5 , 10 , and $25 \mathrm{mg} / \mathrm{jar}$ for maize equal to 5,20 and $50 \mathrm{mg} \mathrm{Cd}$ $\mathrm{kg}^{-1}$ soil, respectively] were prepared with sand and left for 2 weeks to homogenize $\mathrm{Cd}$. The surface sterilized seeds of each crop cultivar were placed in each jar with the help of a sterilized pincer at uniform depth. Light and dark periods were adjusted at 10 and $14 \mathrm{~h}$, respectively, while a temperature of $25 \pm 2{ }^{\circ} \mathrm{C}$ and light intensity of $275 \mu \mathrm{mol} \mathrm{m} \mathrm{m}^{-2} \mathrm{~s}^{-1}$ were maintained during the whole growth period. Treatments were structured in a completely randomized design in factorial arrangement (CRD factorial) with three replicates. At harvesting, tolerance indices (Eq. 2), root/shoot dry biomass, and $\mathrm{Cd}$ uptake were calculated.

$$
\begin{aligned}
& \text { Tolerance indices }(\%) \\
& =\frac{\text { mean root length in Cd or organic amended soil }}{\text { mean root length in control (no Cd or organic amendments) }} \\
& \quad \times 100 \text {. }
\end{aligned}
$$

\section{Shoot and root $C d$}

Shoot and root $\mathrm{Cd}$ contents were determined following the method described by Ahmad et al. (2013). Briefly, the diacid mixture consisting of concentrated nitric acid and perchloric acid in 3:1 ratio was used to digest maize and wheat samples on hot plate until the material became colorless. De-ionized water was added to the flasks and filtered through Whatman \# 40, and the volume made up to $50 \mathrm{~mL}$. The resultant extract was stored in plastic bottles and used for the determination of $\mathrm{Cd}$ on atomic absorption spectrophotometer (PerkinElmer, 100 Analyst, Waltham, USA). Cd uptake in plant tissues (root, shoot, and total plant) and translocation in plants (root to shoot) was calculated using Eq. 3 and Eq. 4 respectively.

$$
\begin{aligned}
& \mathrm{Cd} \text { uptake }(\mathrm{mg} \mathrm{kg}-1 \mathrm{dry} \text { weight }) \\
& =\mathrm{Cd} \text { concentration in plant tissues } \\
& \quad \times \text { respective dry weight }
\end{aligned}
$$

Translocation factor $(\mathrm{TF})=\frac{\mathrm{Cd} \text { concentration in shoot }}{\mathrm{Cd} \text { concentration in root }}$

Cadmium removal efficiency of organic manures

This study was conducted to support the hypothesis that "organic material binds Cd from soil or solution" and thus reduces its bioavailability to plants. The effect of loading rate of $\mathrm{Cd}$ and $\mathrm{pH}$ at a fixed rate of organic manures $(1 \%)$ was studied. Two Cd levels (20 and $40 \mathrm{mg} \mathrm{L}^{-1}$ ) were developed using salt $\mathrm{CdCl}_{2} \cdot \mathrm{H}_{2} \mathrm{O}$. One gram each of compost or BGS was added to $100 \mathrm{~mL}$ of each $\mathrm{Cd}$ level adjusted to $\mathrm{pH} 6$ and 8 in the $250-\mathrm{mL}$ conical flask. Conical flasks were placed in a mechanical shaking incubator at $28 \pm 2{ }^{\circ} \mathrm{C}$ and $100 \mathrm{rpm}$. The samples were drawn after 1 , 6 , and $13 \mathrm{~h}$ from respective flasks to quantify $\mathrm{Cd}$ in solution using an atomic absorption spectrophotometer (PerkinElmer, 100 Analyst, Waltham, USA). Cd removed from artificially polluted water by the application of organic amendments was determined following Eq. 5.

Removal efficiency $(\%)=\frac{\mathrm{Cdi}-\mathrm{Cds}}{\mathrm{Cdi}} \times 100$. 
where Cdi: Initial $\mathrm{Cd}$ concentration $\left(\mathrm{mg} \mathrm{L}^{-1}\right), \mathrm{Cds}: \mathrm{Cd}$ concentration at the time of sampling $\left(\mathrm{mg} \mathrm{L}^{-1}\right)$.

Statistical analysis

Two-way analysis of variance (ANOVA) was carried out to analyze the data using the STATISTIX (version 8.1). The experiment was arranged according to CRD-2 factor factorial design. It comprised of two factors [Factor A: Cd with 4 levels $0,5,20$, and $50 \mathrm{mg} \mathrm{kg}^{-1}$ soil; Factor B: organic amendments with 3 levels, i.e., control, compost, and BGS]. Post hoc HSD Tukey test was used to determine significance between treatment means at $p \leq 0.05$. Correlation of $\mathrm{Cd}$ and organic amendments with different parameters was determined to estimate their relationship at $p \leq 0.01$ and $p \leq 0.05$.

\section{Results and discussion}

Physicochemical characteristics of organic amendments

Table 1 shows analytical results of compost and BGS used in this study. Organic amendments showed slightly higher $\mathrm{pH}$, while the organic matter and mineral contents of nitrogen and heavy metals were within the range of quality standard prescribed by the European and American councils (Brinton 2000).

Effect of organic amendments on wheat and maize

\section{Tolerance indices}

Tolerance indices of wheat decreased sharply (99-86 \%) in response to $\mathrm{Cd}$, but in contrast to this, application of organic amendments increased it (100-112\%) under Cd- stressed conditions (Fig. 1). It was shown from the results that the maximum tolerance indices (112 and $103 \%$ ) were observed with the application of BGS and compost at 5 and $50 \mathrm{mg} \mathrm{kg}^{-1}$ soil, respectively. Similarly, Fig. 1 shows positive influence of organic amendments on tolerance indices of maize, which was increased (116-133\%), as compared to treatment receiving no $\mathrm{Cd}$, and organic amendments (control). Soil amended with BGS showed maximum tolerance (133 and $117 \%$ ) to $\mathrm{Cd}$ applied at the rate of 5 and $50 \mathrm{mg} \mathrm{kg}^{-1}$ soil, respectively, as compared to the control. Our previous study reported inhibitory effects of $\mathrm{Cd}$ on tolerance indices of wheat (Ahmad et al. 2012). However, increased tolerance indices by the application of organic amendments in normal and $\mathrm{Cd}$ stress conferred their positive effect on root growth of studied crops. Likewise, the growth promoting effects of organic amendments in metal-contaminated soil have also been reported earlier (Farrell and Jones 2010; Medina and Azcón 2010).

\section{Plant dry biomass}

The interactive effects $(\mathrm{Cd} \times$ organic amendments $)$ were significant on shoot and total plant biomass (root + shoot), but nonsignificant on root dry biomass of wheat (Table 2). Dry biomass decreased with increasing concentration of Cd. Organic amendments significantly increased shoot, root, and plant dry biomass of wheat in normal and $\mathrm{Cd}$ contaminated soils as compared to their respective controls. However, in normal soil, only the application of BGS increased root dry biomass of wheat significantly as compared to its respective control. The highest shoot $(42 \mathrm{mg}$ plant $^{-1}$ ), root (19 mg plant ${ }^{-1}$ ), and plant biomass (59 mg plant $^{-1}$ ) was obtained with the application of BGS in the treatments receiving 50,0 , and $0 \mathrm{mg} \mathrm{Cd} \mathrm{kg}{ }^{-1}$ soil, respectively.
Fig. 1 Tolerance indices of wheat and maize affected by organic amendments under $\mathrm{Cd}$ stress. Bars show means \pm standard errors

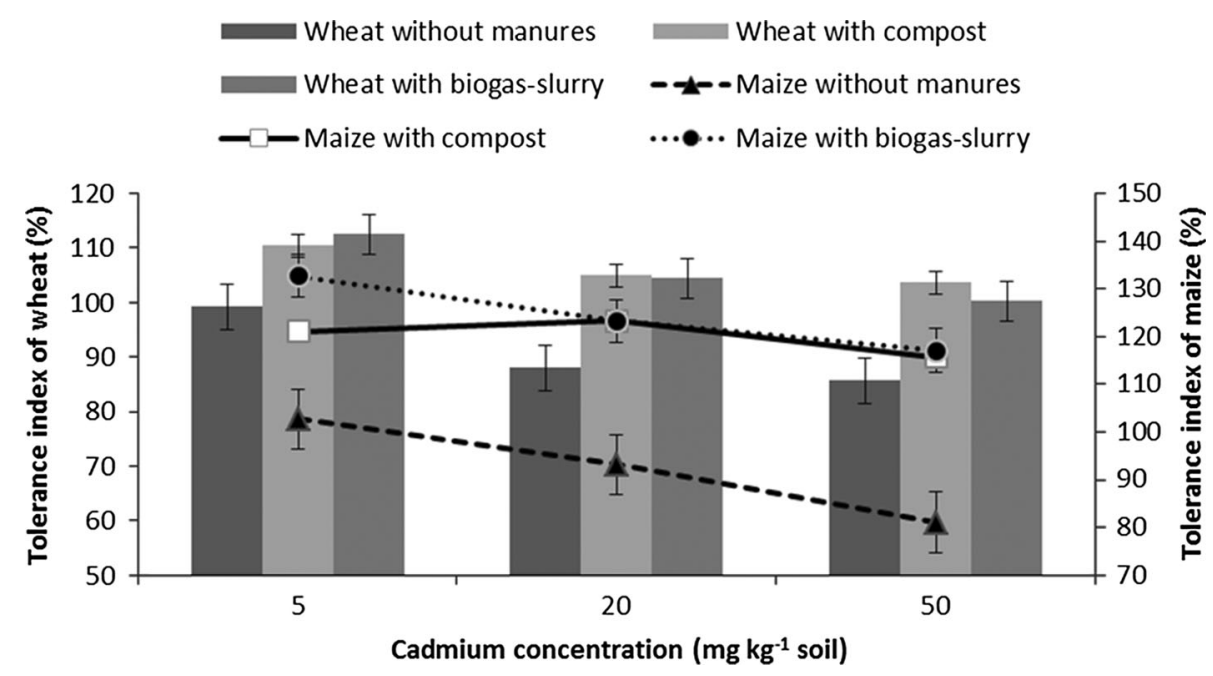


Table 2 Effect of organic amendments on dry biomass and tissue Cd concentration of wheat

\begin{tabular}{|c|c|c|c|c|c|c|c|c|c|c|c|}
\hline \multirow{2}{*}{$\begin{array}{l}\mathrm{mg} \mathrm{kg}^{-1} \text { soil } \\
\text { Cd levels }\end{array}$} & \multirow{2}{*}{$\begin{array}{l}\mathrm{Mg} \mathrm{ha}^{-1} \\
\text { Org. amendments }\end{array}$} & \multicolumn{3}{|c|}{ dry weight (mg plant ${ }^{-1}$ ) } & \multicolumn{3}{|c|}{ Cd conc. $\left(\mathrm{mg} \mathrm{kg}^{-1} \mathrm{dwt}\right)$} & \multicolumn{3}{|c|}{ Cd uptake $\left(\mathrm{mg} \mathrm{kg}^{-1} \mathrm{dwt}\right)$} & \multirow[t]{2}{*}{$\mathrm{TF}$} \\
\hline & & Shoot & Root & Plant & Shoot & Root & Plant & Shoot & Root & Plant & \\
\hline \multirow[t]{3}{*}{0} & Control & $22^{\mathrm{d}}$ & $15.5^{\mathrm{cd}}$ & $37.6^{\mathrm{c}}$ & ND & ND & ND & ND & ND & ND & ND \\
\hline & Compost & $33^{\mathrm{c}}$ & $16.8^{\mathrm{a}-\mathrm{c}}$ & $50.1^{\mathrm{b}}$ & ND & ND & ND & ND & ND & ND & ND \\
\hline & Biogas slurry & $41^{\mathrm{ab}}$ & $18.5^{\mathrm{a}}$ & $59.0^{\mathrm{a}}$ & ND & ND & ND & ND & ND & ND & ND \\
\hline \multirow[t]{3}{*}{5} & Control & $22^{\mathrm{d}}$ & $14.6^{\mathrm{de}}$ & $36.9^{\mathrm{c}}$ & $0.27^{\mathrm{d}}$ & $0.79^{\mathrm{d}}$ & $1.06^{\mathrm{e}}$ & $6.14^{\mathrm{d}}$ & $11.55^{\mathrm{d}}$ & $39.46^{\mathrm{e}}$ & $0.37^{b-c}$ \\
\hline & Compost & $32^{\mathrm{c}}$ & $16.5^{\mathrm{bc}}$ & $49.0^{\mathrm{b}}$ & $0.14^{\mathrm{d}}$ & $0.35^{\mathrm{d}}$ & $0.46^{\mathrm{e}}$ & $3.69^{\mathrm{d}}$ & $5.84^{\mathrm{d}}$ & $22.83^{\mathrm{e}}$ & $0.32^{\mathrm{cd}}$ \\
\hline & Biogas slurry & $39^{\mathrm{b}}$ & $17.4^{\mathrm{ab}}$ & $56.7^{\mathrm{a}}$ & $0.07^{\mathrm{d}}$ & $0.41^{\mathrm{d}}$ & $0.48^{\mathrm{e}}$ & $2.68^{\mathrm{d}}$ & $7.16^{\mathrm{d}}$ & $27.02^{\mathrm{e}}$ & $0.17^{\mathrm{de}}$ \\
\hline \multirow[t]{3}{*}{20} & Control & $21^{\mathrm{d}}$ & $13.1^{\mathrm{e}}$ & $33.7^{\mathrm{d}}$ & $2.64^{\mathrm{c}}$ & $4.81^{\mathrm{c}}$ & $7.45^{\mathrm{d}}$ & $54.11^{\mathrm{c}}$ & $63.32^{\mathrm{c}}$ & $251.1^{\mathrm{d}}$ & $0.55^{\mathrm{a}-\mathrm{c}}$ \\
\hline & Compost & $31^{\mathrm{c}}$ & $16.3^{\mathrm{b}-\mathrm{d}}$ & $47.7^{\mathrm{b}}$ & $2.26^{\mathrm{c}}$ & $3.57^{\mathrm{c}}$ & $5.84^{\mathrm{d}}$ & $71.26^{\mathrm{c}}$ & $58.52^{\mathrm{c}}$ & $279.2^{\mathrm{cd}}$ & $0.64^{\mathrm{ab}}$ \\
\hline & Biogas slurry & $41^{\mathrm{ab}}$ & $17.4^{\mathrm{ab}}$ & $58.5^{\mathrm{a}}$ & $2.23^{\mathrm{c}}$ & $3.91^{\mathrm{c}}$ & $6.14^{\mathrm{d}}$ & $91.86^{\mathrm{c}}$ & $67.80^{c}$ & $359.0^{\mathrm{c}}$ & $0.57^{\mathrm{a}-\mathrm{c}}$ \\
\hline \multirow[t]{3}{*}{50} & Control & $20^{\mathrm{d}}$ & $13.6^{\mathrm{e}}$ & $33.8^{\mathrm{d}}$ & $7.51^{\mathrm{a}}$ & $9.26^{\mathrm{a}}$ & $16.77^{\mathrm{a}}$ & $151.99^{\mathrm{b}}$ & $125.9^{\mathrm{b}}$ & $566.9^{\mathrm{b}}$ & $0.82^{\mathrm{a}}$ \\
\hline & Compost & $32^{\mathrm{c}}$ & $16.0^{\mathrm{b}-\mathrm{d}}$ & $47.8^{\mathrm{b}}$ & $5.11^{\mathrm{b}}$ & $6.75^{\mathrm{b}}$ & $11.85^{\mathrm{c}}$ & $162.71^{\mathrm{b}}$ & $108.2^{\mathrm{b}}$ & $567.7^{\mathrm{b}}$ & $0.76^{\mathrm{a}}$ \\
\hline & Biogas slurry & $42^{\mathrm{a}}$ & $16.5^{\mathrm{bc}}$ & $58.6^{\mathrm{a}}$ & $5.11^{\mathrm{b}}$ & $9.04^{\mathrm{a}}$ & $14.12^{\mathrm{b}}$ & $215.37^{\mathrm{a}}$ & $149.2^{\mathrm{a}}$ & $829.3^{\mathrm{a}}$ & $0.56^{\mathrm{a}-\mathrm{c}}$ \\
\hline \multicolumn{2}{|c|}{ Cadmium $^{\dagger}(\mathrm{df}=3)$} & ns & $*$ & $*$ & $*$ & $*$ & $*$ & $*$ & $*$ & $*$ & $*$ \\
\hline \multicolumn{2}{|c|}{ Organic amendments $^{\dagger}(\mathrm{df}=2)$} & $*$ & $*$ & $*$ & * & $*$ & $*$ & $*$ & $*$ & $*$ & $*$ \\
\hline \multicolumn{2}{|c|}{ Interaction $^{\dagger}(\mathrm{df}=6)$} & $*$ & ns & $*$ & $*$ & $*$ & $*$ & $*$ & $*$ & $*$ & $\mathrm{~ns}$ \\
\hline
\end{tabular}

Compost was applied at the rate of 10 , while biogas slurry at the rate of $15 \mathrm{Mg} \mathrm{ha}^{-1}$ to wheat; control was without organic manures. Means, in each column, sharing same letters differ nonsignificantly at $(p>0.05)$ according to post hoc HSD Tukey test. Values presented in table are means of three replicates

$d f$ degree of freedom, $d w t$ dry weight, $n s$ nonsignificant, $N D$ not detected, $T F$ translocation factor

${ }^{\dagger}$ Asterisk shows significant main and interactive effects at $(p \leq 0.05)$

In contrast to wheat, the interactive effects $(\mathrm{Cd} \times$ organic amendments) were not significant in maize dry biomass, but the main effects were significant in relation to shoot, root, and total plant dry biomass (Table 3). In normal soil, application of compost showed significant increase in shoot, root, and total plant dry biomass of maize; however, BGS also increased total plant dry biomass significantly as compared to their respective controls. The significant increase in shoot and total plant dry biomass of maize was recorded on application of compost at all levels of $\mathrm{Cd}$ contamination as compared to their respective controls. Neither compost nor BGS showed any significant improvement in root dry biomass of maize at all levels of $\mathrm{Cd}$ contamination as compared to their respective controls.

Similar to our findings, Farrell and Jones (2010) observed that application of different types of compost increased above and below ground biomass of plant in contaminated soil, with maximum biomass produced by the application of peat-based compost. In this study, the plant species-specific response of organic amendments was observed, as BGS produced maximum increase in dry biomass in wheat, while compost in maize (Tables 2, 3). However, these organic amendments sharing one similarity that shoot dry biomass of both cereals was affected more significantly than root dry biomass with the addition of these amendments. This might be due to improved soil structure, nutrient, and water-holding capacity of soil in response to organic amendments, as similar effects on soil properties after the addition of compost and BGS were observed earlier by Oldare et al. (2011). Organic amendments increased biomass of studied crops in Cd-contaminated soil, which is in line with Farrell and Jones (2010) and in contrast with Rosario et al. (2007). This alleviation of phytotoxicity in response to organic amendments may be credited to improved physical health of soil and nutrient availability (Oldare et al. 2011; Abubaker et al. 2012). However, the added organic amendments may also bring new organisms (bacteria, fungi, actinomycetes etc.) that may increase nutrient cycling, produce hormones, and establish symbiosis with plants to enable better stress tolerance. It was reported earlier that soil microbial activity increased upon addition of compost (Lejon et al. 2007). Moreover, BGS enhanced indigenous microbial activity (Oldare et al. 2008, 2011) and prevented crop diseases (Yu et al. 2006). Our results are consistent with those of Tiwari et al. (2000) who reported that crop performance was increased by the application of BGS might be due to increased ammonium nitrogen in digested BGS (Monnet 2003). This study clearly demonstrates the positive effects of organic amendments on restoration of contaminated land and successful establishment of green cover in the form of plants. A large amount of waste produced during agricultural activities can be converted into compost and biogas 
Table 3 Effect of organic amendments on dry biomass and tissue Cd concentration of maize

\begin{tabular}{|c|c|c|c|c|c|c|c|c|c|c|c|}
\hline \multirow{2}{*}{$\begin{array}{l}\mathrm{mg} \mathrm{kg}^{-1} \text { soil } \\
\text { Cd levels }\end{array}$} & \multirow{2}{*}{$\begin{array}{l}\mathrm{Mg} \mathrm{ha}^{-1} \\
\text { Org. amendments }\end{array}$} & \multicolumn{3}{|c|}{ dry weight (mg plant ${ }^{-1}$ ) } & \multicolumn{3}{|c|}{ Cd conc. (mg kg ${ }^{-1}$ dwt) } & \multicolumn{3}{|c|}{ Cd uptake (mg kg $\left.{ }^{-1} \mathrm{dwt}\right)$} & \multirow[t]{2}{*}{$\mathrm{TF}$} \\
\hline & & Shoot & Root & Plant & Shoot & Root & Plant & Shoot & Root & Plant & \\
\hline \multirow[t]{3}{*}{0} & Control & $223^{\mathrm{cd}}$ & $150^{\mathrm{b}-\mathrm{d}}$ & $373^{\mathrm{cd}}$ & ND & ND & ND & ND & ND & ND & ND \\
\hline & Compost & $330^{\mathrm{a}}$ & $193^{\mathrm{a}}$ & $523^{\mathrm{a}}$ & ND & ND & ND & ND & ND & ND & ND \\
\hline & Biogas slurry & $280^{\mathrm{a}-\mathrm{c}}$ & $183^{\mathrm{ab}}$ & $463^{\mathrm{ab}}$ & ND & ND & ND & ND & ND & ND & ND \\
\hline \multirow[t]{3}{*}{5} & Control & $230^{\mathrm{cd}}$ & $143^{\mathrm{cd}}$ & $373^{\mathrm{cd}}$ & $0.27^{\mathrm{bc}}$ & $0.70^{\mathrm{d}}$ & $0.97^{\mathrm{d}}$ & $60.8^{\mathrm{b}}$ & $100.8^{\mathrm{c}}$ & $362^{\mathrm{c}}$ & $0.39^{\mathrm{cd}}$ \\
\hline & Compost & $327^{\mathrm{a}}$ & $180^{\mathrm{a}-\mathrm{c}}$ & $507^{\mathrm{a}}$ & $0.11^{\mathrm{bc}}$ & $0.32^{\mathrm{d}}$ & $0.43^{\mathrm{d}}$ & $35.1^{\mathrm{b}}$ & $57.5^{\mathrm{c}}$ & $216.9^{c}$ & $0.34^{\mathrm{cd}}$ \\
\hline & Biogas slurry & $257^{\mathrm{b}-\mathrm{d}}$ & $167^{\mathrm{a}-\mathrm{d}}$ & $423^{\mathrm{bc}}$ & $0.13^{\mathrm{bc}}$ & $0.39^{\mathrm{d}}$ & $0.52^{\mathrm{d}}$ & $35.3^{\mathrm{b}}$ & $64.1^{\mathrm{c}}$ & $222.5^{\mathrm{c}}$ & $0.34^{\mathrm{cd}}$ \\
\hline \multirow[t]{3}{*}{20} & Control & $200^{\mathrm{d}}$ & $130^{\mathrm{d}}$ & $330^{\mathrm{d}}$ & $2.92^{\mathrm{b}}$ & $4.12^{\mathrm{c}}$ & $7.04^{\mathrm{c}}$ & $586.4^{\mathrm{b}}$ & $534.9^{\mathrm{b}}$ & $2322.6^{\mathrm{b}}$ & $0.72^{\mathrm{bc}}$ \\
\hline & Compost & $313^{\mathrm{ab}}$ & $163^{\mathrm{a}-\mathrm{d}}$ & $476^{\mathrm{ab}}$ & $2.22^{\mathrm{bc}}$ & $2.81^{\mathrm{c}}$ & $5.03^{\mathrm{c}}$ & $694.5^{\mathrm{b}}$ & $457.4^{\mathrm{b}}$ & $2400.5^{b}$ & $0.82^{\mathrm{a}-\mathrm{c}}$ \\
\hline & Biogas slurry & $237^{\mathrm{cd}}$ & $153^{\mathrm{b}-\mathrm{d}}$ & $390^{\mathrm{cd}}$ & $2.55^{\mathrm{bc}}$ & $2.97^{\mathrm{c}}$ & $5.52^{\mathrm{c}}$ & $605.4^{\mathrm{b}}$ & $443.3^{\mathrm{b}}$ & $2139.1^{b}$ & $0.91^{\mathrm{a}-\mathrm{c}}$ \\
\hline \multirow[t]{3}{*}{50} & Control & $200^{\mathrm{d}}$ & $137^{\mathrm{d}}$ & $337^{\mathrm{d}}$ & $10.35^{\mathrm{a}}$ & $7.62^{\mathrm{a}}$ & $17.97^{\mathrm{a}}$ & $2062.9^{\mathrm{a}}$ & $1038.5^{\mathrm{a}}$ & $6036.9^{\mathrm{a}}$ & $1.38^{\mathrm{a}}$ \\
\hline & Compost & $317^{\mathrm{ab}}$ & $157^{\mathrm{a}-\mathrm{d}}$ & $473^{\mathrm{ab}}$ & $8.17^{\mathrm{a}}$ & $5.87^{\mathrm{b}}$ & $14.04^{\mathrm{b}}$ & $2586.2^{\mathrm{a}}$ & $922.1^{\mathrm{a}}$ & $6652.9^{\mathrm{a}}$ & $1.38^{\mathrm{a}}$ \\
\hline & Biogas slurry & $227^{\mathrm{cd}}$ & $143^{\text {cd }}$ & $370^{\mathrm{cd}}$ & $8.71^{\mathrm{a}}$ & $6.75^{\mathrm{ab}}$ & $15.46^{\mathrm{ab}}$ & $1993.3^{\mathrm{a}}$ & $972.8^{\mathrm{a}}$ & $5725.7^{\mathrm{a}}$ & $1.30^{\mathrm{ab}}$ \\
\hline \multicolumn{2}{|c|}{ Cadmium $^{\dagger}(\mathrm{df}=3)$} & $*$ & $*$ & $*$ & $*$ & $*$ & $*$ & $*$ & $*$ & $*$ & $*$ \\
\hline \multicolumn{2}{|c|}{ Organic amendments ${ }^{\dagger}(\mathrm{df}=2)$} & $*$ & $*$ & $*$ & ns & $*$ & $*$ & ns & ns & ns & ns \\
\hline \multicolumn{2}{|c|}{ Interaction $^{\dagger}(\mathrm{df}=6)$} & $\mathrm{ns}$ & $\mathrm{ns}$ & ns & ns & $\mathrm{ns}$ & ns & ns & ns & ns & ns \\
\hline
\end{tabular}

Compost and biogas slurry both applied at the rate of $15 \mathrm{Mg} \mathrm{ha}^{-1}$ to maize; control was without organic manures. Means, in each column, sharing same letters differ nonsignificantly at $(p>0.05)$ according to Post hoc HSD Tukey test. Values presented in table are means of three replicates

$d f$ degree of freedom, $d w t$ dry weight, $n s$ nonsignificant, $N D$ not detected, $T F$ translocation factor

${ }^{\dagger}$ Asterisk shows significant main and interactive effects at $(p \leq 0.05)$

and may be applied to restore contaminated site. Likewise, it has also been suggested that organic amendments can also be used to extract and stabilize organic and inorganic pollutants present in the soil and may be used successfully to establish plants (Farrell and Jones 2010; Tejada et al. 2008).

\section{Tissue Cd concentration and translocation}

Results in Table 2 demonstrate tissue Cd concentration and its uptake in wheat plant [root, shoot, and total plant (root + shoot)] in amended and non-amended soil. The main and interactive effects were significant, which means that the exogenous application of $\mathrm{Cd}$ and organic amendments both influenced tissue $\mathrm{Cd}$ concentration and its uptake in wheat. Tissue $\mathrm{Cd}$ concentration of wheat decreased in amended soil at all levels of Cd contamination, but the results were significant only at higher $\mathrm{Cd}$ level. Compost significantly decreased shoot, root, and total plant Cd concentration, while BGS significantly decreased shoot and total plant $\mathrm{Cd}$ concentration of wheat at $50 \mathrm{mg} \mathrm{Cd}$ $\mathrm{kg}^{-1}$ soil as compared to their respective controls. Likewise, $\mathrm{Cd}$ uptake in wheat decreased at lower $\mathrm{Cd}$ level (5 mg Cd kg ${ }^{-1}$ soil), but increased at higher $\mathrm{Cd}$ level (20 mg Cd kg $\mathrm{mg}^{-1}$ soil) upon addition of organic amendments in comparison with respective control, although these differences were not significant. Cd uptake increased significantly at $50 \mathrm{mg} \mathrm{Cd} \mathrm{kg}^{-1}$ soil in soil amended with BGS as compared to its respective control. Cd translocation from root to shoot was increased with increasing exogenous application of $\mathrm{Cd}$; however, organic amendments nonsignificantly reduced $\mathrm{Cd}$ translocation in comparison with control. BGS application caused 2.17- and 1.46-fold reduced translocation in wheat at 5 and $50 \mathrm{mg} \mathrm{Cd} \mathrm{kg}^{-1}$ soil as compared to their respective controls (Table 2; Fig. 2).

Tissue $\mathrm{Cd}$ concentration and uptake in maize (shoot, root, and total plant) was directly proportional to $\mathrm{Cd}$ applied in soil which was significantly higher with each other except shoot $\mathrm{Cd}$, which showed nonsignificant differences at 5 and $20 \mathrm{mg} \mathrm{Cd} \mathrm{kg}^{-1}$ soil (Table 3). Application of compost showed significant decreased $\mathrm{Cd}$ concentration in root and total plant as compared to their respective controls. None of the organic amendment showed significant differences in root, shoot, and total plant $\mathrm{Cd}$ uptake of maize. Cd translocation from maize root to shoot was directly related to its concentration in soil. Organic amendments nonsignificantly decreased/increased the $\mathrm{Cd}$ translocation from root to shoot depending on $\mathrm{Cd}$ concentration in soil (Table 3; Fig. 2).

Tissue $\mathrm{Cd}$ concentration in wheat and maize was greatly reduced in the presence of organic amendments; however, it can be seen from the results that tissue $\mathrm{Cd}$ concentration and its uptake depends upon plant species and its concentration in soil (Tables 2, 3). Addition of organic 
Fig. 2 Effect of organic amendments on translocation factor $(\mathrm{TF})$ of $\mathrm{Cd}$ in wheat and maize. Bars show means \pm standard errors

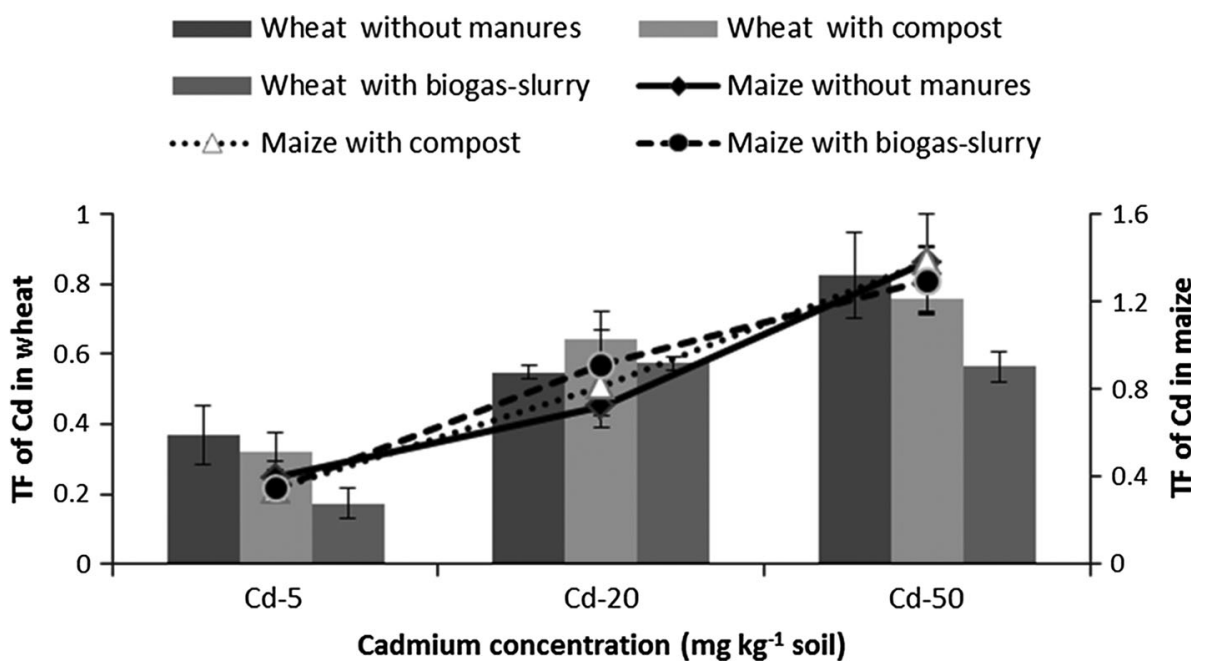

amendments can immobilize or stabilize $\mathrm{Cd}$ in soil by forming stable metalo-organo complexes that might have restricted $\mathrm{Cd}$ uptake in aerial part of plants. Dourado et al. (2013) reported that immobilization of $\mathrm{Cd}$ in soil is one of the mechanisms for increased plant biomass in metalcontaminated soil. Further, they argued that $\mathrm{Cd}$ immobilization may be helpful to reduce its toxicity on root proliferation; thereby, plants may uptake better nutrients in normal and stressed conditions. In this study, dry biomass of plants (wheat and maize) significantly increased in $\mathrm{Cd}$ contaminated soil, which might be due to immobilization of Cd in amended soil (Tables 2, 3). Businelli et al. (2009) reported reduction in the bioavailability of metals in soil amended with organic matter, while Rajaie et al. (2006) reported highest metal availability in soil after addition of organic matter to soil. Bioavailable fraction of metals depends upon soil characteristics, climatic conditions, and the native microbial activity that converts compost and other organic material into mineral form (Clemente et al. 2006). Moreover, the reduction in $\mathrm{Cd}$ concentration could have occurred due to progressive binding of $\mathrm{Cd}$ to added organic amendments which are known for numerous metalbinding sites (Wang and Staunton 2006; Sebastia et al. 2008; Businelli et al. 2009). In this study, addition of compost had the most promising effect on $\mathrm{Cd}$ stabilization as compared to BGS. This suggests that $\mathrm{Cd}$ phytoavailability to plants may possibly be decreased with the application of compost. Concurrent to this $\mathrm{Cd}$ reduction, it has been reported that compost induced a gradual alkalinization of soil which would induce precipitation of $\mathrm{Cd}$ as hydroxides and carbonates making it less bioavailable to plant (Kumpiene et al. 2007). Our results show that $\mathrm{Cd}$ translocation was higher in maize $(\mathrm{TF}=1.38$ at $50 \mathrm{mg} \mathrm{Cd}$ $\mathrm{kg}^{-1}$ soil) than wheat ( $\mathrm{TF}=0.82$ at $50 \mathrm{mg} \mathrm{Cd} \mathrm{kg}^{-1}$ soil); this implied that $\mathrm{Cd}$ translocation from root to shoot depends upon plant species and the concentration of $\mathrm{Cd}$ applied in soil. Organic amendments were shown to decrease $\mathrm{Cd}$ translocation significantly only in wheat (Table 2; Fig. 2). According to classification reported by Zhang et al. (2002) and Fayiga and Ma (2006) plant would be hyperaccumulator if TF values $>1$ and excluder if TF values $<1$. According to this classification, wheat plant does not qualify for hyperaccumulator, while maize plant qualifies based on $\mathrm{TF}$ values at higher $\mathrm{Cd}$ level $(50 \mathrm{mg} \mathrm{Cd}$ $\mathrm{kg}^{-1}$ soil). Cd uptake in plants significantly increased in soil amended with BGS, which may be due to increased biomass of the plant (Tables 2, 3). Moreover, Cd uptake depends upon transpiration rate of plant species (Mobin and Khan 2007), and it may also differ in plant species and genotypes (Metwally et al. 2005). Our results reported similar findings that $\mathrm{Cd}$ uptake was higher in maize than wheat (Tables 2, 3). This study did not report Cd effect on physiology and antioxidant activities; however, these may be included in future research to better understand the mechanism of Cd uptake in plants from soil amended with organic manures.

\section{Correlation between parameters}

Table 4 shows the relationship of $\mathrm{Cd}$ and organic amendments with different wheat and maize parameters. A strong correlation was found between exogenous application of $\mathrm{Cd}$ and its accumulation in the roots, shoots, and total plants of wheat and maize. However, addition of organic amendments inhibited $\mathrm{Cd}$ accumulation in aerial and underground parts of both cereals, but the results were nonsignificant. The negative sign showed that $\mathrm{Cd}$ significantly decreased dry biomass of plant, particularly root; however, addition of organic amendments significantly increased dry biomass of both cereals, particularly wheat. Organic amendments showed strong correlation with growth parameters of wheat $(r=0.98$ for shoot dry weight 
and $r=0.83$ for root dry weight) as compared to maize ( $r=0.30$ for shoot dry weight and $r=0.40$ for root dry weight), indicating that their effects were species dependent (Table 4). This strong relationship may possibly be due to significant reduction in $\mathrm{Cd}$ at higher level of $\mathrm{Cd}$ contamination in wheat as compared to maize in organic amended soil (Tables 2,3). This immobilization of Cd may

Table 4 Correlation between different parameters of wheat and maize with $\mathrm{Cd}$ and organic amendments

\begin{tabular}{|c|c|c|c|c|}
\hline \multirow[t]{2}{*}{ Parameters } & \multicolumn{2}{|l|}{ Wheat } & \multicolumn{2}{|l|}{ Maize } \\
\hline & Cadmium & $\begin{array}{l}\text { Org. } \\
\text { amendments }\end{array}$ & Cadmium & $\begin{array}{l}\text { Org. } \\
\text { amendments }\end{array}$ \\
\hline Shoot dwt & $-0.02^{\mathrm{ns}}$ & $0.98^{* *}$ & $-0.24^{\mathrm{ns}}$ & $0.30^{\mathrm{ns}}$ \\
\hline Root dwt & $-0.37 *$ & $0.83^{* *}$ & $-0.53^{* *}$ & $0.40^{*}$ \\
\hline Plant dwt & $-0.09^{\mathrm{ns}}$ & $0.98^{* *}$ & $-0.36^{*}$ & $0.36^{*}$ \\
\hline Root Cd conc. & $0.94 * *$ & $-0.05^{\mathrm{ns}}$ & $0.93^{* *}$ & -0.09 \\
\hline $\begin{array}{l}\text { Shoot Cd } \\
\text { conc. }\end{array}$ & $0.89 * *$ & $-0.12^{\mathrm{ns}}$ & $0.87^{* *}$ & -0.06 \\
\hline Plant Cd conc. & $0.92 * *$ & $-0.08^{\mathrm{ns}}$ & $0.91^{* *}$ & -0.07 \\
\hline $\begin{array}{c}\text { Root Cd } \\
\text { uptake }\end{array}$ & $0.94 * *$ & $0.05^{\mathrm{ns}}$ & $0.94^{* *}$ & $-0.05^{\mathrm{ns}}$ \\
\hline $\begin{array}{l}\text { Shoot Cd } \\
\text { uptake }\end{array}$ & $0.90 * *$ & $0.13^{\mathrm{ns}}$ & $0.87^{* *}$ & $-0.01^{\mathrm{ns}}$ \\
\hline $\begin{array}{l}\text { Plant Cd } \\
\text { uptake }\end{array}$ & $0.91 * *$ & $0.13^{\mathrm{ns}}$ & $0.91^{* *}$ & $-0.03^{\mathrm{ns}}$ \\
\hline
\end{tabular}

Asterisk shows significant differences at $p \leq 0.01^{* *}$ and $p \leq 0.05^{*}$ $d w t$ dry weight, $n s$ nonsignificant be due to enhanced microbial activity in organic amended soil because it has been reported that high organic matter contents can favor native microbial community, which may stabilize Cd in soil (Farrell et al. 2010). In this study, microbial dynamics in organic amended soil were not studied in the presence of trace metals, but it would be beneficial to investigate such relations to better understand the metal-microbe-organic matter relationship.

Cadmium removal efficiency of organic amendments

The effectiveness of compost and BGS to remove or sorb $\mathrm{Cd}$ affected by the application of varying doses of $\mathrm{Cd}(20$, $\left.40 \mathrm{mg} \mathrm{L}^{-1}\right)$ at two $\mathrm{pH}$ levels $(6,8)$ and various time intervals (1, 6 and $13 \mathrm{~h})$ was also investigated. Both organic amendments (compost and BGS) showed promising results in terms of their capacity to remove $\mathrm{Cd}$ from solution (Fig. 3). Both organic amendments showed 70-95\% Cd removal efficiency under varying conditions. Another important factor is $\mathrm{pH}$, which can also influence $\mathrm{Cd}$ uptake. It was noted that two units increase in $\mathrm{pH}$ of the solution influenced $\mathrm{Cd}$ uptake in solution. It observed that $\mathrm{pH} 8$ favored more $\mathrm{Cd}$ removal from solution as compared to $\mathrm{pH}$ 6. Cadmium removal by organic amendments was also influenced by time. In the current study, Cd removal by organic amendments depended on time; it was also found that maximum $\mathrm{Cd}$ removal occurred after $13 \mathrm{~h}$ of exposure. The compost removed 71 and $73 \% \mathrm{Cd}$ (initial concentration $20 \mathrm{mg} \mathrm{L}^{-1}$ ) from solution after $1 \mathrm{~h}$ while 83
Fig. 3 Cadmium removal from solution at $\mathrm{pH} 6(\mathrm{a}, \mathrm{c})$ and $\mathrm{pH} 8$ (b, d), effects of different cadmium loading rates $(20$, $\left.40 \mathrm{mg} \mathrm{L}^{-1}\right)$, contact time (1, 6, $13 \mathrm{~h}$ ), and organic amendments (compost and biogas slurry at fixed rate of $1 \%$ ). Bars show means \pm standard errors
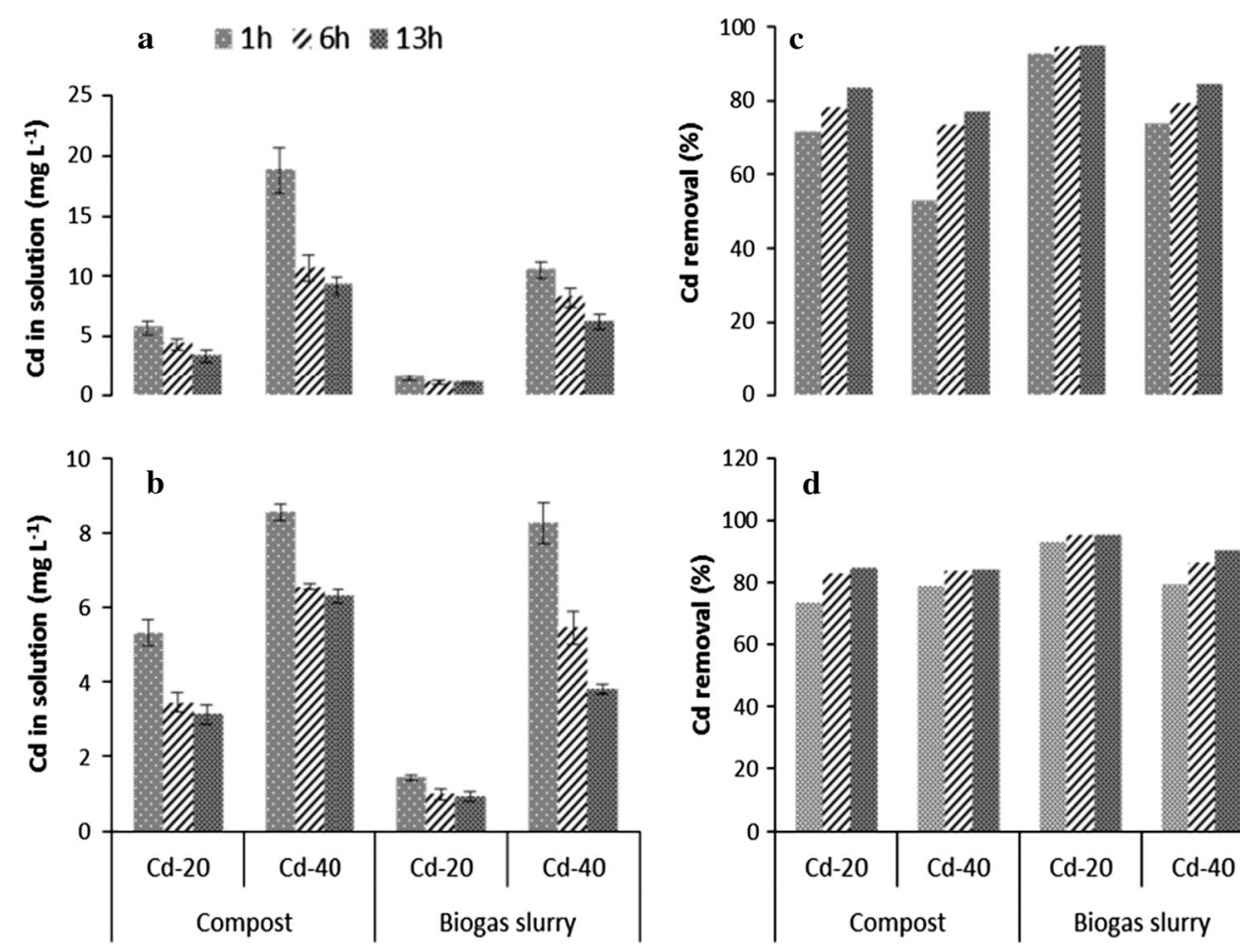
and $84 \%$ after $13 \mathrm{~h}$ at $\mathrm{pH} 6$ and 8, respectively. Biogas slurry removed 93 and $95 \%$ Cd (initial concentration $20 \mathrm{mg} \mathrm{L}^{-1}$ ) from solution after 1 and $13 \mathrm{~h}$, respectively, at both $\mathrm{pH}$ (6 and 8). However, at increasing Cd concentration $\left(40 \mathrm{mg} \mathrm{L}^{-1}\right)$ compost removed $77-84 \%$, whereas BGS $84-90 \%$ at different $\mathrm{pH}$ values. Moreover, with the changing $\mathrm{pH}$ conditions, dramatic changes in Cd removal were observed. Overall, the BGS was more effective in $\mathrm{Cd}$ removal from artificially Cd-polluted water as compared to compost. The results of the study inferred that the organic amendments are capable of remediating artificially $\mathrm{Cd}$ polluted water depending upon time, concentration of the pollutant, and $\mathrm{pH}$ of the media.

The acidity and alkalinity of solution have great impact on biosorption of metals. It happens because most of the metals are frequently available under acidic conditions. The capacity of different biomaterials to sorb metals varies at different $\mathrm{pH}$ levels, while maximum biosorption of metals was reported to occur at $\mathrm{pH}$ 6 (Sari and Tuzen 2009). In contrast to this, our results inferred that $\mathrm{pH} 8$ was ideal for $\mathrm{Cd}$ removal from solution. Moreover, at higher $\mathrm{pH}$, the biomaterial surfaces have most of negatively charged groups (hydroxyl, carboxyl, amino, and amide) that form complexes with the available cation $\left(\mathrm{Cd}^{2+}\right)$. Thus, biosorption might occur between adsorbate and adsorbent (Sari and Tuzen 2009; Rahaman et al. 2008). The results of this study showed that $\mathrm{Cd}$ might have bound to applied organic amendments that helped in $95 \% \mathrm{Cd}$ removal after $13 \mathrm{~h}$ from artificially Cd-polluted water. We cannot neglect the effect of time, $\mathrm{pH}$, and metal concentration in the removal of $\mathrm{Cd}$, because increased contact time may have enhanced $\mathrm{Cd}$ removal depending on the $\mathrm{pH}$ and actual metal concentration in the solution.

\section{Conclusion}

Results demonstrated that organic amendments may not only be used as soil conditioner, but these are also capable to stabilize $\mathrm{Cd}$ in soil. Organic amendments (compost and BGS) are effective soil amendments to increase plant biomass in normal and Cd-contaminated soil. Compost can stabilize $\mathrm{Cd}$ in the presence of plants; however, BGS can be used for removal of $\mathrm{Cd}$ from wastewater. Further, research should focus on the effect of organic amendments on physiology of wheat and maize in relation to its uptake in plants in metal-contaminated soil. These results provide good preliminary data and provide ground for further exploitation of organic amendments (compost and BGS) to remove other inorganic and organic pollutants from soil and water based on kinetic, laboratory, and field-oriented studies.
Acknowledgments The authors greatly acknowledge "Higher Education Commission (HEC) of Pakistan" to provide financial support for this project under the Indigenous 5000 Fellowship Scheme Batch IV.

\section{References}

Abubaker J, Risberg K, Pell M (2012) Biogas residues as fertilisersEffects on wheat growth and soil microbial activities. Appl Energy 99:126-134

Ahmad I, Akhtar MJ, Zahir ZA, Jamil A (2012) Effect of cadmium on seed germination and seedling growth of four wheat (Triticum aestivum L.) cultivars. Pak J Bot 44:1569-1574

Ahmad I, Akhtar MJ, Asghar HN, Zahir ZA (2013) Comparative efficacy of growth media in causing cadmium toxicity to wheat at seed germination stage. Int J Agric Biol 15:517-522

Azzaoui S, El Hanbali M, Leblance M (2002) Copper, lead, iron and manganese in the Sebou drainage basin; sources and impact on surface water quality. Water Qual Res J Canada 37:773-784

Brinton WF (2000) Compost quality standards and guidelines. Final report. Prepared for: New York State Association of Recyclers. Woods End Research Laboratory, Inc. p. 1-42

Businelli D, Massaccesi L, Said-Pullicino D, Gigliotti G (2009) Longterm distribution, mobility and plant availability of compostderived heavy metals in a landfill covering soil. Sci Total Environ 407:1426-1435

Clemente R, Escolar Á, Bernal MP (2006) Heavy metal fractionation and organic matter mineralisation in contaminated calcareous soil amended with organic materials. Bioresour Technol 97:1894-1901

Conceição FT, Navarro GRB, Silva AM (2013) Anthropogenic influences on $\mathrm{Cd}, \mathrm{Cr}, \mathrm{Cu}, \mathrm{Ni}, \mathrm{Pb}$ and $\mathrm{Zn}$ concentrations in soils and sediments in a watershed with sugar cane crops at São Paulo State, Brazil. Int J Environ Res 7:551-560

Dourado MN, Martins PF, Quecine MC, Piotto FA, Souza LA, Franco MR, Tezotto T, Azevedo RA (2013) Burkholderia sp. SCMS54 reduces cadmium toxicity and promotes growth in tomato. Ann Appl Biol 163:494-507

El-Said AG, Badawyand NA, Garamon SE (2010) Adsorption of cadmium (II) and mercury (II) onto natural adsorbent rice husk ash (RHA) from aqueous solutions: study in single and binary system. J Am Sci 6:400-409

Farrell M, Jones DL (2010) Use of composts in the remediation of heavy metal contaminated soil. J Hazar Mater 175:575-582

Farrell M, Griffith GW, Hobbs PJ, Perkins WT, Jones DL (2010) Microbial diversity and activity are increased by compost amendment of metal-contaminated soil. FEMS Microbiol Ecol 71:94-105

Fayiga AQ, Ma LQ (2006) Using phosphate rock to immobilize metals in soils and increase arsenic uptake in Pteris vittata. Sci Total Environ 359:17-25

Hussain N, Hassan G, Arshadullah M, Mujeeb F (2001) Evaluation of amendments for the improvement of physical properties of sodic soil. Inter J Agric Biol 3:319-322

Isaac RA (1998) AOAC official method 985.01. Metals and other elements in plants. In: Cunniff $\mathrm{P}$ (ed) Official methods of analysis of AOAC international, 16th edn, Gaithersburg, Maryland

Jackson ML (1962) Soil chemical analysis. Prentice Hall, Inc., Wood Cliffs

Kumpiene J, Lagerkvisk A, Maurice C (2007) Stabilization of Pb- and $\mathrm{Cu}$ contaminated soil using coal fly ash and peat. Environ Pollut $145: 365-373$

Lejon DPH, Sebastia J, Lamy I, Chaussod R, Ranjard L (2007) Relationships between soil organic status and microbial 
community density and genetic structure in two agricultural soils submitted to various types of organic management. Microb Ecol 53:650-663

Mahmood T (2010) Phytoextraction of heavy metals the process and scope for remediation of contaminated soils. Soil Environ 29:91-109

Medina A, Azcón R (2010) Effectiveness of the application of arbuscular mycorrhiza fungi and organic amendments to improve soil quality and plant performance under stress conditions. J Soil Sci Plant Nutr 10:354-372

Metwally A, Safronova VI, Belimov AA, Dietz KJ (2005) Genotypic variation of the response to cadmium toxicity in Pisum sativum L. J Exp Bot 409:167-178

Moaref S, Sekhavatjou MS, Hosseini Alhashemi A (2014) Determination of trace elements concentration in wet and dry atmospheric deposition and surface soil in the largest industrial city, Southwest of Iran. Int J Environ Res 8:335-346

Mobin M, Khan NA (2007) Photosynthetic activity, pigment composition and antioxidative response of two mustard (Brassica juncea) cultivars differing in photosynthetic capacity subjected to cadmium stress. J Plant Physiol 164:601-610

Monnet F (2003) Digested biomass as fertiliser. Available online: http://www.landbrugsraadet.dk/view.asp?ID=2281

Muhammad S, Müller T, Joergensen RG (2007) Compost and P amendments for stimulating microorganisms and maize growth in a saline soil from Pakistan in comparison with a nonsaline soil from Germany. J Plant Nutr Soil Sci 170:745-751

Oldare M, Pell M, Svensson K (2008) Changes in soil chemical and microbiological properties during 4 years of application of various organic residues. Waste Manag 28:1246-1253

Oldare M, Arthurson V, Pell M, Svensson K, Nehrenheim E, Abubakar J (2011) Land application of organic waste-effects on the soil ecosystem. Appl Energy 88:2210-2218

Pérez-de-Mora A, Burgos P, Madejón E, Cabrera F, Jaeckel P, Schloter M (2006) Microbial structure and function in a heavy metal contaminated soil: effects of plant growth and different amendments. Soil Biol Biochem 38:327-341

Pérez-de-Mora A, Madrid F, Cabrera F, Madejón E (2007) Amendments and plant cover influence on trace element pools in a contaminated soil. Geoderma 139:1-10

Rahaman MS, Basu A, Islam MR (2008) The removal of As(III) and $\mathrm{As}(\mathrm{V})$ from aqueous solutions by waste materials. Bioresour Technol 99:2815-2823

Rajaie M, Karimian N, Maftoun M, Yasrebi J, Assad MT (2006) Chemical forms of cadmium in two calcareous soil textural classes as affected by application of cadmium enriched compost and incubation time. Geoderma 136:533-541

Rosario K, Iverson SL, Henderson DA, Chartrand S, McKeon C, Glenn EP, Maier RM (2007) Bacterial community changes during plant establishment at the San Pedro River mine tailings site. J Environ Qual 36:1249-1259
Sari A, Tuzen M (2009) Biosorption of As(III) and As(V) from aqueous solution by macrofungus (Inonotus hispidus) biomass: equilibrium and kinetic studies. J Hazar Mater 164:1372-1378

Sarwar G, Hussain N, Schmeisky H, Muhammad S (2007) Use of compost an environment friendly technology for enhancing ricewheat production in Pakistan. Pak J Bot 39:1553-1558

Sebastia J, van Oort F, Lamy I (2008) Buffer capacity and Cu affinity of soil particulate organic matter (POM) size fractions. Eur J Soil Sci 59:304-314

Shahbaz M, Akhtar MJ, Ahmed W, Wakeel A (2014) Integrated effect of different $\mathrm{N}$-fertilizer rates and bioslurry application on growth and N-use efficiency of okra (Hibiscus esculentus L.). Turk J Agric For 38:311-319

Taghinia HA, Basavarajappa HT, Qaid Saeed AM (2010) Heavy metal pollution in Kabini River sediments. Int $\mathrm{J}$ Environ Res 4:629-636

Tejada M, Gonzalez JL, Hernandez MT, Garcia C (2008) Application of different organic amendments in a gasoline contaminated soil: effect on soil microbial properties. Bioresour Technol 99:2872-2880

Tiwari VN, Tiwari KN, Upadhyay RM (2000) Effect of crop residues and biogas slurry incorporation in wheat on yield and soil fertility. J Indian Soc Soil Sci 48:515-520

Vassilev A, Tsonev T, Yordanov I (1998) Physiological response of barley plants (Hordeum vulgare) to cadmium contamination in soil during ontogenesis. Environ Pollut 103:287-293

Vutukuru SS (2003) Chromium induced alterations in some biochemical profiles of the Indian major carps, Labeorohita (Hamilton). Bull Environ Contam Toxicol 70:118-123

Walker DJ, Clemente R, Roig A, Bernal MP (2003) The effects of soil amendments on heavy metal bioavailability in two contaminated Mediterranean soils. Environ Pollut 122:303-312

Walker DJ, Clemente R, Bernal MP (2004) Contrasting effects of manure and compost on soil $\mathrm{pH}$, heavy metal availability and growth of Chenopodium album $\mathrm{L}$. in a soil contaminated by pyritic mine waste. Chemosphere 57:215-224

Wang G, Staunton S (2006) Evolution of water-extractable copper in soil with time as a function of organic matter amendments and aeration. Eur J Soil Sci 57:372-380

Yu F, Guan X, Zhao Z, Zhang M, Guo P, Pan J, Li S (2006) Application of biogas fermentation residue in Ziziphus jujuba cultivation. Ying Yong Sheng Tai Xue Bao 17:345-347

Zaniewicz-Bajkowska A, Rosa R, Franczuk J, Kosterna E (2007) Direct and secondary effect of liming and organic fertilization on cadmium content in soil and in vegetables. Plant Soil Environ 53:473-481

Zhang WH, Cai Y, Tu C, Ma QL (2002) Arsenic speciation and distribution in an arsenic hyperaccumulating plant. Sci Total Environ 300:167-177 